\title{
The Inflamed Argentina of Vogue Paris
}

Daniela Novelli

Doutora, Universidade do Estado de Santa Catarina/ daniela.novalli@udesc.br Orcid: 0000-0001-6981-8933 / lattes

Sent 13/11/2018/Acept 21/02/2019 


\title{
The Inflamed Argentina of Vogue Paris
}

\begin{abstract}
The French edition of Vogue magazine published in February 2006, entirely devoted to Argentina, including the fashion editorial Tango des Passions, symbolically revealed the approximation of cultural transmission links between Europe and Argentina, based on a discursive construction based on the philia - one of the fundamental attitudes that govern the representation of the Other in intercultural dialogue. Produced by Carine Roitfeld and photographed by Mario Testino, it was interpreted in the lighting of Daniel-Henri Pageaux's theory, which placed the appreciation of the "culture looked" at the center of a permanent tension whose mirror reflects an explicitly duplicated "I-narrator" as a double [white] body of European high fashion. Vogue Paris establishes an ambiguous and inflamed intercultural dialogue, whether through "bubbling temperament", "fashion theater", "Latin excess" or "stunning pain" attributed to the image of Argentina and its own image
\end{abstract}

Keywords: Vogue Paris; Argentina; the Other's image. 


\title{
A Argentina Inflamada De Vogue Paris
}

\begin{abstract}
RESUMO
A edição francesa do periódico Vogue publicada em fevereiro de 2006, inteiramente consagrada à Argentina, incluindo o editorial de moda Tango des Passions, revelou simbolicamente a aproximação dos laços de transmissão cultural entre a Europa e a Argentina, a partir de uma construção discursiva baseada na philia - uma das atitudes fundamentais que regem a representação do Outro no diálogo intercultural. Realizado por Carine Roitfeld e fotografado por Mario Testino, foi interpretado à luz da teoria de Daniel-Henri Pageaux, que colocou a valorização da "cultura olhada" no centro de uma tensão permanente, cujo espelho reflete um "Eu-narrador" explicitamente duplicado, como um duplo corpo [branco] da alta moda europeia. Seja pelo "temperamento borbulhante", pelo "teatro da moda", pelo "excesso latino" ou ainda pela "dor estonteante" atribuídos à imagem da Argentina e à sua própria imagem, Vogue Paris estabelece um diálogo intercultural ambíguo e inflamado.
\end{abstract}

Palavras-chave: Vogue Paris; Argentina; imagem do Outro. 


\section{INTRODUCTION}

In February 2006, the Vogue Paris magazine honors Argentina ${ }^{1}$. According to its editor-in-chief, it is a country with a bubbly temperament, "a near-blood link with Europe mixed with Latin excessiveness and dizzying suffering-capital" (Roitfeld, 2006a, p. 72). Firstly, it should be taken into account that all ad-justification allows for the understanding of certain qualification procedures, as Daniel-Henri Pageaux (2007) points out, and in this case it was possible to notice that it is the result of a whole symbolic work about the image of Argentina, produced by the French edition ${ }^{2}$. Fashion, cinema, cuisine and literature are intertwined to seduce, ignite and positivize the intercultural dialogue at stake.

Philia is one of the fundamental attitudes that guide the representation of the Other. It is when "the foreign cultural truth is taken for granted, gaining its place in a culture that looks at it, which in turn is a welcoming culture, also held to be positive" (PAGEAUX, 2007, p. 48). The words chosen by the magazine at the opening of the issue reveal that the two cultures are noticed as complementary, and then a change is already possible in the eyes of Vogue. However, identifying the markers of recognition of the Other as "Other" is not always evident, nor even sufficient to guarantee the permanent will of a privileged intercultural dialogue - for a simple act of goodwill can be explained by the concern to reestablish a certain equilibrium broken by phobias or manias. There are hierarchical relationships that assert themselves over the body of the Other, as well as in diverse manifestations of their culture and of their value system.

\footnotetext{
1 This edition analyzed is part of a postdoctoral research carried out at the Université Paris-Sorbonne, with the grant CAPES BEX 6682/14-6 (Brazil).

${ }^{2}$ Vogue Paris numéro 864 Février 2006. Due to the non-permission of the copyright to use the images of the analyzed editorial, these were deleted from this article. This edition is available for consultation in the collection of the Bibliothèque des Arts Décoratifs under code JP 168.
} 
In the twentieth century, Latin America functions as a laboratory in which it is easy, on the one hand, to see the monopoly of a 'modeling' Europe of models crumble; and on the other hand, to verify, in certain cases, the reversal of the sense of transference. Moreover, this does not mean that Europe and Latin America do not yet participate in the same supraregional cultural ensemble (ROLLAND, 2011, p. 83, our translation).

\section{ARGENTINA "EMBRACED": THE OTHER OF THE SAME?}

The fashion editorial titled Tango des Passions was produced by Carine Roitfeld and photographed by Mario Testino. Mariacarla Boscono and Patricia Schmid, the models chosen for shooting, also made the issue hood, dressed in black and red. Already in the first two pages, it is possible to capture almost instinctively the atmosphere of the "theater of fashion" offered by Buenos Aires and all its living forces: it is at once inflamed, audacious, sensual, authentic and elegant.

The magazine seeks to bring the positive and doubly recognized appreciation of the "most Parisian of the Argentina cities" (ROITFELD, 2006b, p. 182), playing with the symbology of "double", from which a whole sequence is programmed, and that transmitted images are arranged in a enough stablished way from the point of view of the looking culture [regardante] (PAGEAUX, 2007).

Juciane Cavalheiro and Rosana Fonseca (2011) analyzed literary tales of the famous Argentine writer Jorge Luis Borges, among them L'Autre, le Même and, according to the researchers, being "the Other of the same" implies in an interior and exterior paradox, contradictory and complementary at the same time, which causes to the original "I" extreme emotional reactions, such as fascination and aversion to his "Other". Thus the appreciation of Vogue's culture is at the center of a permanent tension, whose intercultural mirror where French and Argentina's people look 
at each other reflects an explicitly duplicated "I-narrator", a double [white] body of European high fashion.

Then you can find a strong similarity between the two models: they have the same short hair (except that they are in radically opposite colors); they wear the same models of sandals (silver and high heels), the same elements wrapped around their arms and appear to be dressed in the same black outfit. But this game of dualities is replete with small differences, revealed by the image and the anchoring text: the young blond hair model wears a top and a slightly evaé and bright leather skirt, while the young model of black hair uses a dress straight and opaque. In addition, the black pieces are signed by Yohji Yamamotto (Japanese minimalist creator), who was the protagonist of the deconstructionist movement and whose stories inspired the German filmmaker Wim Wenders to deal with fashion in the film "Identity of ourselves" in 1989.

Choices that seem very appropriate to the theme of the theater of fashion, for all the deconstructed and androgynous subtlety mixes with a very high dose of sensuality and desire. The Italian model Boscono owns the hair in blonde platinum, color of the 1930s Hollywood actresses, that have become true sexual symbols, like Jean Harlow; it has in fact a physical constitution associated with the androgynous body, with opal skin, a rock chic style (where black predominates). In 2006, the same year of this Vogue production, she ventured into the dramatic arts. It is the fashion à la folie (VOGUE PARIS, 2006, p.181) that approaches and / or confronts. In fact, the Argentine writer Alan Pauls witnessed it in the heading "Magazine":

[...] in Buenos Aires, [...] you are confronted with the subtlety of an oscillation, a back-and-forth between the familiar and the foreign, the known and the unknown, the same as the other. Even if the definitive links to Europe (among others, a population essentially of Italian, Spanish or Jewish origin), Buenos Aires is not a 
European city: it is almost one. It is precisely in this almost that it inhabits its charm (PAULS, 2006, p. 211, our translation).

The mediatic discourse produced by Vogue partially tunes to what Marcel Peyrouton wrote in the 1950s: "Buenos Aires, under the dust of an evolution, takes the form of an American village, and yet the soul is Latin, nobly, and still more: French and even Parisian" (1950, apud ROLLAND, 2000, p.103, our translation). It should be noted that this Frenchman met Argentina in the 1930 s and later he was ambassador to this country twice (1936-1940 and 1941-1942), as well as minister of Vichy in this interval. In the same vein, André Siegfried stated that "a Frenchman in Latin America is never completely foreigner" (apud ROLLAND, 2000, p. 93), at the invitation of the Institute of the University of Paris in 1937.

Rita Segato (apud FRIERA, 2012, p.12) reminds us that the myth of the melting pot wants at all costs to ensure the idea that the Argentina is a mixture of European nationalities. This kind of "absence of otherness" between Buenos Aires and Paris is, however, limited on the one hand to Latin American and European elites and on the other hand to a reductionist perception. But according to Denis Rolland (2000, p.94, our translation) it is "almost always involuntary, coming more durably from the French elites than from the successive generations of the Latin American elites".

Like the "two Borges" of Borges's tale - a man weakened by loneliness and blindness and another man much younger invented perhaps by the author himself (Cavaleiro and Fonseca, 2010) - the different gestures of the two characters of Vogue seem to reveal in the scene an ambiguity implied in this mirroring: the body of the blond model (of the "Inarrator") is an active body, who wants to embrace the Other or himself's body, in this perspective a passive body. The protagonists of Vogue, like many characters created by Borges, seem "to have no pleasure in meeting with 
themselves, because when they do so they are in a dreamlike setting or clearly at the point of dying" (Cavaleiro and Fonseca, 2011). In fact, their relationships seem to release something absolutely passional and obscure, fueled by a kind of "disturbing emotion between fiction and reality" (Rachline, 2006b, 265, our translation).

The visual language of Vogue Paris evidences a dialogue between the "I-narrator" and the Other, in scenes full of symbolic components (Cavalheiro and Fonseca, 2011), among them the horse. The history of riding - be it court, military or sports - and even the use of this animal, refer to the universe of hunting, war, transportation and tradition. The horse that appears in Tango des Passions has elegant, blood-like, fast, manly, intelligent and manageable bearing. In the picture, half of his body is hidden behind the models, but his appearance is surprising, since he is soaked in water and soap; his look is directed at the two young women, reinforcing the importance of the double in the scene.

Next to the animal, there is a young strong white model with trunk on display, wearing white Levi's pants and long riding boots; his look, thrown out of the scene, is the same indefinable look of the Brazilian model Jeisa, in the editorial of another French edition of Vogue, dedicated to Brazil. However, if the white capoeira trousers found in the latter represented an African cultural heritage, now Levi's white trousers appeared as one of the symbols associated with the cultural inheritance of the polo-sport game of royalty for excellence.

Therefore, there is an approximation of the links of cultural transmission between Europe and Argentina, through the manipulation of signs of the universe of social elites that, in Argentina of the 20th century, presented a visible obsession with horse racing and a preference for games of random (BETHELL, 1992). In addition, the chic neighborhood of 
Palermo preserves a glamorous aura especially after the year 2000, becoming home to several film and television producers and becoming recognized as "Palermo Hollywood". Finally, all this calls for a better understanding of the "states of cultural dependence that have made France [Paris de Francia!] an active model for South America" (PAGEAUX, 2007, p. 53, our translation).

No other Latin country is as well versed in polo as Argentina, a court game brought to the country by English immigrants in the late nineteenth century. Buenos Aires hosts a polo championship called the "Palermo Open" since the year 1893, raising over time the same attention given to football. The sport made its first Olympic appearance in the city of Paris in the early twentieth century.

Pierre-Marie Taillepied [le Comte de Bondy], a politician engaged with the Argentina club, described quite enthusiastically in Le Miroir du Monde magazine: "As a spectacle, [the polo] offers a fiery entanglement of broken lines, which pleases his contrast with the calm and eternal curved lines of the decoration". Such a discourse of the early twentieth century already revealed a very refined aesthetic perception of this formal ambiguity, which made polo a sport attractive both for the vision offered and for the atmosphere created around it - a formula taken up by Vogue Paris in 2006.

\section{THE BARBECUE AS LATIN EXAGGERATION}

At the beginning of the twentieth century, Argentina reached the position of important world exporter of cereals and beef, being still the third power in export of live stock, cattle and horses. Vogue Paris makes of this reference one of the most significant cultural traditions of the country: the barbecue. Almost always associated with the landscapes of the pampas [prairies] and the mythical figure of the gaucho (Argentine cowboy), this "sacred culinary art" is usually 
prepared on Sunday and consumed with family or friends, keeping alive a "vocation" historically associated with the image of the country, as well as Uruguay and southern Brazil. Roast is therefore a cultural tradition maintained by the inhabitants of a considerable part of South America, where the preparation and consumption of the meat imply diverse habits and social relations. Argentina is the largest consumer of beef in the world.

The second image analyzed in the French editorial shows the figure of a rotisserie, the person who takes care of the preparation and cooking of the meat, that appears to the left wearing blue jeans, white shirt and a long white apron tied around the waist. Right in front of him, a huge grill full of meat, with charcoal underneath. In the background, leafy trees with green leaves to the left of the image and a grayish sky to the right, with a few more less luminous trees. One can say that the magazine seeks to stage a symbolic efficacy of this popular tradition of Argentina and South American cuisine, whose duplicate "Inarrator" is once again the result of a paradoxical dialogue, both contradictory and complementary.

The same models, Boscono and Schmid are valued for their luminosity and their voluminous silk musseline dresses printed with Japanese flowers, signed by the brand Comme des Garçons - created by King Kawakubo, whose style questions the normality of established aesthetic concepts). Thus unfinished clothing, unstructured silhouettes, and disproportionate volumes may materialize the desire to preserve some incorrigible spirit or libertarian insolence, common between the two cultures (Argentine and French), perhaps brought about by the crystallization of the revolutionary principles of 1789 - which, according to Denis Rolland (2000, p. 93) constituted the "golden age" of a 
dominant republican model in Latin America in the first three decades of the twentieth century.

It is important to point out that it is not a cultural tradition linked to the legacies of the modern English or French elites, as was the case with the polo game. At stake is a Hispanic-American (roasted) folk tradition, which becomes a conceptual catalyst for the representation of the Other; despite the uncertainty of its origin, the barbecue is directly associated with the pastoral regions of Spain, being in fact a symbol of the gastronomy of Castile, where nomadic people of the XVIII century tasted the lamb meat. His preparation required only an oven and a clay dish. In Argentina, beef is prepared mostly by men, who bake charcoal-grilled enormous pieces arranged on a grill. The gauchos became real experts in the elaboration of the asado a la cruz, when a great iron utensil is buried in the ground and surrounded by fire of farm wood.

The Latin exaggeration associated with high fashion sold at Vogue Paris goes through the flesh and clothing, that is, the two greatest savoir-faire of Argentina and France. This representative image of respected culture forms part of a discourse that seeks to incarnate the spirit of avant-garde and excellence in creativity. The discourse and creativity of the French nation, "for whom fashion functions as a sign, has been increasingly reified by an introspective and bourgeois cultural paradigm" says Kate Best (2008, p. 7, our translation).

In the En Vogue section of this edition of 2006, the magazine speaks of a return to the Latin glamor of the $1950 \mathrm{~s}$ (POIBLANC, 2006), which brings a touch of audacity and excess, as well as "sex appeal at once raw and civilized" (PAULS, 2006, p.221, our translation). There is, therefore, in this barbecue image another paradox comparable to the Argentina's capital, seen by the writer Pauls (2006, p. 211, 
our translation) as being "both modern and peripheral, global and still a little provincial". The symbology of the double plays here between the strange and the familiar, without necessarily considering them as opposites. The body of the "Other of the same" is positioned more toward the middle of the scene, moving toward the place of this supposedly unappreciated tradition, whose look releases curiosity and aversion; his double, the "I-narrator" keeps his look toward the camera (or the observer) but retains the first gently, since he knows that "exoticism implies a certain contact and juxtaposition of worlds" (Leitão, 2007, p. 273).

However, the absence of interaction between the "Inarrator" (including its double) and the Other (the baker) in the analyzed image may indicate the preservation of difference, typical of postmodern ambivalence, which risks ignoring alterity and culture from the Other.

\section{SUFFERING AT PLEASANT FRONTIERS}

In the Magazine section, Vogue affirms that the Argentina dictatorship has become a "memory that has not just unfolded in the present, a living wound, even in generations that have not lived it" (RACHLINE, 2006b, p. 264, our translation). In addition, the editor-in-chief of the edition, Carine Roitfeld, points to Buenos Aires as the "dizzying capital-suffering, of colliding dictatorships and crises, of which one of the most surprising consequences is a stubbornness to keep the head at all costs for top "(ROITFELD, 2006a, p.72). Driven, therefore, by a certain obsession with showing the image of the "Other living beside the Self", the magazine launches itself in this third moment of the editorial in an evocative atmosphere of suffering, resulting from an appropriate mixture of excess, passion, fantasy and ingenuity [naïveté]. 
This kind of excess sensitivity - evidenced in fact as a Latin characteristic and associated with the image of Argentina in this edition - comes in the face of the vanguard art produced by Vogue in some editorials, establishing a strong conceptual and artistic dialogue with the universe of luxury by the bias of contemporary fashion. In this sense, it can be said that the production of this image is halfway to the "camp" style, aesthetic attitude turned to the artifice and the exaggeration, well commented in the 1960 s by the American essayist and novelist Susan Sontag. She states that this style is "a way of proving, of finding her pleasure without being embarrassed by a judgment of value" (SONTAG, 2010, p. 327, our translation), cynicism and malice being pure artifices.

The French imaginary about the vertiginous Argentine suffering intends to be less serious and more pleasurable in this scenario of "fashion theater", taking advantage of the "perpetual tension between aesthetics and morality" (SONTAG, 2010, p. 322). On the left, the "I-narrator", incarnating the [white] body of fashion by the blonde Boscono, is more forgiving of the wound of the Other, for he is still the "Other of the same" - it is therefore a double indulgence. Still open wound, undigested trauma, the hand of the model on the belly is part of this symbolic process of representation of the Other; the "I-narrator" needs his "Other" to learn the best of (re) knowing himself - if it is to remember the trauma, to dream in a different way or just to live more at ease with the "European bad conscience about the third-world" (SEGURA, 2005, p. 147, our translation).

Perhaps it is precisely at the heart of this tension that regarded culture experiences such an ambiguous condition as the memory of its own pain: the two crutches held close to the body and the partially suspended feet approach the physical sequels found in the two great world wars - and not necessarily during the period of the most severe military and 
civilian dictatorship between 1976 and 1983 by the Argentines, whose most serious consequences involved missing persons, torture, diversion of goods and hostages.

If the pallor of the deficiency symbolizes a serious and monochromatic dialogue, the camp in this case reminds us that the experience of suffering in Vogue can be seen from the aesthetic angle. In the image, France is valued as a mirror of its own historical influence on 21st Argentina's century and its cultural tradition in the fields of sewing and decoration, said haut de gamme: the model wears a black silk taffeta dress signed by Chanel, traditional French brand of luxury fashion with classic and timeless style; wears Balenciaga leather sandals by Nicolas Ghesquière (French avant-garde style creator) and silver "death-head" bracelet signed by Tom Binns (Irish breeder of high jewelery, with original style).

There is still another dated sign in this image, which refers to the European universe, more precisely to French furniture: wooden armchair with metal studs and coated with the Jouy toile print - also present on the wall. This Indian cotton fabric was manufactured by the manufacture of Christophe-Philippe Oberkampf in 1760, near the Court of Versailles; on the structure were depicted bucolic or mythological scenes of characters, who became certified as coming from that place (appelation française). It is noted in this dream camp a kind of mythification of that historical time and eventually narrative.

In relation to foreign space, the different field plans assigned to each side of the pages immediately reveal a differentialist dialogue of recognition of the Other, despite the apparent desire of the magazine to give visibility to the two countries - projecting itself around the philia.

According to Pageaux (2007), the process of (re) organization of foreign space is constantly marked by the opposition "I" vs. "Other", more precisely in these two 
images: the city (house, hotel) vs. camp (pampa), proximity familiar, colored) vs distance (unknown, black and white), in (European culture) vs. outside (South American nature). These confirm the fact that all culture is also defined in opposition to the others. In fact, the bonds between the looking-for identity and the altered look are always complex, as Mauricio Segura (2005) warned.

Guided by the "tension between aesthetic and moral" (SONTAG, 2010, p. 322, our translation), Vogue operates on the right a slip of the sense of injury, making it eroticized. Suffering seems to change polarity, since the double is also associated with the subject of death and the desire for survival, recalling Cavalheiro and Fonseca (2011) about Borges's short story, L'Autre, le Même.

Thus, the "I-narrator", always duplicated in the "Other of the same", experiences a symbolic ambivalence created by passionate interest and terror in the face of otherness: on the one hand, it would seek for the protection of a complete destruction - more to be ensured by the durable appearance of a France as the "common political and cultural denominator federative of many Latin American elites sensitive to this French universalism", according to Emmanuel Todd (1983 apud ROLLAND, 2000, p. 86, our translation); and, on the other, the "I-narrator" would experience the threat of death by his double, perceived as "scary messenger of desire" - on the scene thanks to eroticism. Referring to Georges Bataille, for whom life and freedom are inseparable from death, MarieChristine Lala wrote:

From the fear and terror bordering on obscenity, hopelessness and drunkenness, to the limits of exhaustion and sobbing where we do not know whether we will laugh or cry, when the charm of death and that of nakedness equals, it is suddenly the blast - with the indifference and passion of laughing together (LALA, 1985, p. 71). 
In fact, for Bataille (1957 apud LIPPI, 2008, our translation), eroticism is essentially the "domain of violence, of violation", since it is the experience of an unlimited desire until death, the Other or itself. Vogue's eroticized staging is the "negative" of violence: it goes through the contained violence, the retention of energy, the only way to guide the identity crisis, according to Lala (1985). Was it a French identity that was "bruised"? Or of an "exotic" and "deprived" Latin American alterity?

The Argentine society of the early twentieth century was a sui generis rural society, for "many peasants were authentic pioneers endowed with the same buying and energetic mentality of their brothers from other countries" (BETHELL 1992, p. 75). Certain symbols of unbridled force and freedom in Argentina's rural culture (horses, earth, trees from the pampas region) are directly confronted with the closure and even entrapment of bodies, gaining themselves the vertiginous symbolic power.

As the "I-narrator" moves toward the immeasurable, it moves toward the Other - or loss, in the sense attributed to eroticism by Bataille (LIPPI, 2008). The gestures of the characters go through an "authentic physical experience" (ROITFELD, 2006a, p.72, our translation), with the arms locked in fences of barbed wire: the two young models play with the defeated, the exhausted, the hopeless and the brave, the invincible, the provocative. Both release what Vogue Paris has captured from Argentina: "the sex appeal, the mystery and the contradictions of this tempted capital that fascinates" (Vogue Paris, 2006, page 210, our translation).

In the middle of the field, Mariacarla Boscono wears a silk crepe dress with a tubular neckline and silicone details; Patricia Schmid wears a dress trimmed in cotton gabardine molded to the body. The two pieces are signed by Hussein Chalayan, Cypriot and British creator of experimental and 
conceptual style. In order for "the charm of death and nakedness to equal," Vogue chose precisely a creator who wonders about the world, politics, war, and religion, about issues such as uprooting and identity, isolation and oppression. If pleasure also implies a certain disappearance (LIPPI, 2008), perhaps a loss is symbolically revealed by the ambiguities of desire and bodies in Vogue Paris in this third moment of representation about Argentina.

\section{FINAL CONSIDERATIONS}

The images analyzed in the fashion editorial Tango de Passions demonstrated how much Vogue Paris tried to develop certain processes of evaluation and reinterpretation of Argentina in order to stage the Other living next to the "Inarrator", reinforcing precisely the idea of a culture with welcoming look, which takes culture looked at as equally positive.

However, many of the historical and sociocultural aspects involving France and Argentina which were observed placed the mirror of an explicitly duplicated "I-narrator" at the center of a permanent tension, symbolically acting as a double [white] body of European high fashion. Vogue Paris establishes an ambiguous and inflamed intercultural dialogue, whether through "bubbling temperament", "fashion theater", "Latin excess" or "stunning and pleasurable pain" attributed to the image of Argentina and its own image.

\section{REFERÊNCIAS}

BEST, Kate Nelson. Fashioning the figure of French Creativity: a historical perspective on the political function of French Fashion Discourse. Web Journal of Media French Studies, 2008. 
BETHELL, Leslie. Argentina en 1914: las pampas, el interior, Buenos Aires. In: BETHELL, L. (org.). Historia de América latina. 10. América del Sur, c. 1870-1930. Barcelona: Editorial Crítica, 1992. pp. 67-88.

CAVALHEIRO, Juciane; FONSECA, Rosa Maria Tavares. O duplo em Borges: análise dos contos "O Outro", "O sul", "O inverossímel impostor Tom Castro" e "O morto". Anuário de Literatura, Florianópolis, v. 16, n. 1, p. 154-170, june 2011. ISSN 2175-7917.

FRIERA, Silvina. O mito é antipolítico, pois a política é discutível. Entrevista com o antropólogo Alejandro Grimson. Instituto Humanitas Unisinos, 21 de novembro de 2012. Disponível em: http://www.ihu.unisinos.br/noticias/515719o-mito-e-antipolitico-pois-a-politica-e-discutivel-entrevistacom-o-antropologo-alejandro-grimson. Acesso em 10 jan. 2015.

LALA, Marie-Christine. La pensée de Georges Bataille et I'oeuvre de la mort. In: Littérature, n. 58, 1985. Le savoir de l'écrit. Pp. 60-74.

LEITÃO, Débora Krischke. Brasil à moda da casa: imagens da nação na moda brasileira contemporânea. Tese de Doutorado (Programa de Pós-Graduação em Antropologia Social) - Instituto de Filosofia e Ciências Humanas Universidade Federal do Rio Grande do Sul: Porto Alegre, 2007. 373 p.

LIPPI, Silvia. «Introduction », Transgressions, Toulouse, ERES , «Point Hors Ligne», 2008, 264 pages. Disponível em: www.cairn.info/transgressions--9782749209753-page-

11.htm. Acesso em 10 fev. 2015

PAGEAUX, Daniel-Henri. Littératures et cultures en dialogue. Paris: L'Harmattan, 2007.

PAULS, Alan. Ville aux trésors. Vogue Paris. Paris: Les Publications Condé Nast S. A., n. 864, février 2006. p. 210211

POIBLANC, Ludivine. Evita. Vogue Paris. . Paris: Les Publications Condé Nast S. A., n. 864, février 2006. p. 83-88

RACHLINE, Sonia. Cinéma vérités. Vogue Paris. Paris: Les Publications Condé Nast S. A., n. 864, février 2006b. p. 260265

ROITFELD, Carine. Le point de vue de Vogue. Vogue Paris. Paris: Les Publications Condé Nast S. A., n. 864, février 2006a. p. 72 
. Tango des passions. Vogue Paris. Paris: Les Publications Condé Nast S. A., n. 864, février 2006b. p. 182203

ROLLAND, Denis. La crise du modèle français. Marianne et I'Amérique latine: culture, politique et identité. Rennes, Presses Universitaires de Rennes, 2000.

L'Amérique latine et la France: acteurs et réseaux d'une relation culturelle. Rennes: Presses Universitaires de Rennes, 2011.

SEGURA, Mauricio. La faucille et le condor: le discours français sur l'Amérique latine, 1950-1985. Montréal: Les Presses de I'Université de Montréal, 2005.

SONTAG, Susan. L'oeuvre parle (Oeuvres completes, vol. 5). Paris, Christian Bourgois, coll. "Titres", 2010.

VOGUE PARIS. Paris: Les Publications Condé Nast S.A., n. 864, février 2006. 